\title{
A Crack in the Foundation? Revisiting ECR's Voluntary Tenet
}

JULIA M. WONDOLLECK

Voluntary participation is a long-standing tenet of environmental conflict resolution, prescribed at a time when the eventual reach and character of ECR could only be imagined. Today, ECR processes are ubiquitous, varied, and not always voluntary. Voluntary engagement involves choice and perception of fairness instilling commitment, good faith, respectful exchange, and legitimacy. These essential process qualities can be compromised if participation is mandated, yet mandates are sometimes necessary. This disconnect between theory and practice has been extensively examined for court-connected ADR involving civil disputes, but not for ECR involving public disputes. Mediator experience with mandated ECR processes warrants attention.

$\mathrm{V}$

oluntary participation is a long-standing tenet of the environmental conflict resolution (ECR) field, prescribed at a time when the eventual reach and character of ECR could only be imagined. Today, ECR processes are ubiquitous, varied, and not always voluntary. However, the voluntary tenet has never been revisited; nor have the implications for practice been explicitly examined for those processes in which parties do not engage voluntarily. This article attempts to unravel the logic implicit in the longstanding prescription that collaborative ECR processes be voluntary. It asks which qualities associated with a voluntary process have made it a central tenet of ECR theory and what the shortcomings are when a process is compelled or mandated instead. In other words, what might be lost if voluntary engagement is compromised? Finally, it assesses the implications for

\section{WWILEY}

InterScience

Conflict Resolution Quarterly, vol. 27, no. 3, Spring 2010 @ Wiley Periodicals, Inc. and the Association for Conflict Resolution • DOI: 10.1002/crq.261 
process dynamics and management when participation is not fully voluntary and concludes with a proposition for a revised perspective on the voluntary tenet.

\section{ECR: From Theory and Concept to Embedded Practice}

Thirty years ago, examples of multiparty collaboration involving environmental issues were few and far between. Today, ECR processes are widespread and encompass varied forms and applications. As Dukes (2004) describes it:

The vocabulary that at one point favored mediation has expanded to include terms such as consensus building, collaboration, collaborative learning, collaborative planning, collaborative natural resource management, community-based collaboration, and community-based conservation. Many practitioners would include enhanced public involvement within their practice as well [pp. 191-192; italics in original].

Although collaboration that is focused on environmental problems has become commonplace, ECR processes are nonetheless not uniform in origin, structure, or even purpose (Margerum, 2008). Some processes are agency-initiated while others emerge organically from within communities of place or interest (Koontz and others, 2004; Weber, 2003; Wondolleck and Yaffee, 2000). Some are triggered by conflict while others arise from shared concern about a place or recognition of a common problem (Bernard and Young, 1996; Brick and Snow, 2000). Some encompass many interrelated issues and have a long time horizon; others focus on a few issues to be resolved in a limited time frame (Agranoff, 2007; Heikkila and Gerlak, 2005; Lurie, 2004). Some are upstream, policy development processes while others are downstream, focused on programs and sitespecific disputes (O'Leary and Bingham, 2003; Sabatier and others, 2005). Some enlist the assistance of professional third parties, while others do not benefit from formal intervention (Dukes, 2004). Regardless of their origin, focus, and time frame, all exhibit the core characteristics that define ECR: "direct, face-to-face discussions; deliberation intended to enhance participants' mutual education and understanding; inclusion of multiple sectors representing diverse and often conflicting perspectives; openness and flexibility of process; and consensus or some variation other than unilateral decision making as the basis for agreements" (Dukes, 2004, p. 191). 
Unlike ADR in civil cases connected to the courts that involve a limited number of parties, discrete issues, and short time periods in private processes (Hedeen, 2005; Wissler, 2002), ECR processes involve many parties over an extended time period, often dealing with a multiplicity of interrelated and evolving issues in a highly transparent public process. ECR processes focus on public issues and involve government agencies, nongovernmental organizations, citizens, scientists, and business interests. The value of collaborative ECR processes to management of increasingly "wicked" public problems that are unstructured, cross-cutting, and relentless is well recognized (Weber and Khademian, 2008).

Much has changed in the three decades since ECR emerged as an idea to be tested and early theory was developed. Today, win-win has become part of the common vernacular in American society, and collaboration is a frequent topic in policy discussions. As Emerson and colleagues describe this:

Public and private stakeholders continue to turn to ECR and indeed have extended this innovation over the past thirty years beyond its initial application in the litigation context, to other applications upstreamto the enforcement arena, to rule making, and to policy and site-specific plan development. Federal and state laws have been created, including the Administrative Dispute Resolution Act and the Negotiated Rulemaking Act, to clarify and broaden the use of ECR. Administrative programs have been established-among them, the Conflict Prevention and Resolution Center at the U.S. Environmental Protection Agency, the Collaborative Action and Dispute Resolution Center at the U.S. Department of Interior, and the U.S. Institute for Environmental Conflict Resolution at the Morris K. Udall Foundation-to build infrastructure and garner resources to support more ECR. Indeed, the underlying principles of the field are now being drawn on by some federal agencies to overhaul internal management practices and reform individual and programmatic performance measures [Emerson, O'Leary, and Bingham, 2004, p. 221].

ECR has expanded from largely ad hoc application in site- or issuespecific situations to now being embedded in agency programs and procedures.

With this dramatically expanded landscape of ECR activity, it is now worth revisiting some of the field's initial prescriptions, which were proposed at a time when the eventual reach and character of ECR could only be imagined. As Emerson and colleagues (2004) observe, "One of the most 
difficult challenges for ECR research is the heterogeneity of the ECR processes themselves as well as the diversity of applications and intended effects" (p. 222). In fact, Dukes (2004) posed the question about differences between "programmatic processes and those that develop organically" and discovered that "this element has barely been examined" (p. 210). Today there exist variations on the initial ECR model, with mandated or compulsory mediation among them. The genesis of individual ECR processes, in particular whether they are voluntary, is not inconsequential to their dynamics. Though little examined, such distinctions have both theoretical and practical implications.

\section{Why Mandate ECR?}

Management of many environmental and natural resource issues-particularly those at the scale of ecosystems - requires collaboration across multiple stakeholders and agencies because no single party possesses the knowledge, authority, resources, and capabilities to manage such issues alone (Agranoff, 2007; Heikkila and Gerlak, 2005; Weber and Khademian, 2008; Wondolleck and Yaffee, 2000). However, this imperative for collaboration is not always matched by a parallel interest in collaboration by those who are party to the conflict. Many of these issues reside in a political and organizational context that can resist collaboration. Whether it is agencies protecting turf and maintaining control (Bardach, 1998) or parties firmly rooted in an adversarial mind-set (Golann, 1989), situations exist where parties are not inclined to engage even if by all objective measures their interests would be better served by so doing (Katz, 1993; SPIDR, 1991). Sometimes those agency managers who are best positioned to initiate or support a process are resistant. Nabatchi (2007) details a long list of reasons public managers may readily dismiss collaboration, among them

inertia, fear of losing control and incurring oversight, and lack of knowledge, resources, high-level support, and incentives . . pervasive litigation mentality, fear of looking weak, the perception that ADR is a passing fad, lack of experience, negative experiences, perverse incentives, lack of settlement authority, and concerns about confidentiality [p. 647].

For collaboration to occur in such situations, ECR needs to be nudged, or even required. Sometimes reluctant or skeptical parties must be compelled to give a process a chance. 
Voluntary participation, for good reason, is a central tenet embedded in theories of collaboration and dispute resolution, but not all ECR processes are voluntary. There are no fewer than four mandated collaborative processes for the USDA Forest Service alone (Cheng, 2006). The Secure Rural Schools and Community Self-Determination Act of 2000 mandates that the Forest Service collaborate with local communities in resource advisory councils "whether they want to or not, or know how to or not" (Leahy, 2006, pp. 5-6). The Clean Air Act statutorily mandates the U.S. EPA to resolve selected disputes involving tribes and the states through collaborative negotiation processes (Van de Wetering and McKinney, 2006). NOAA and other federal agencies have been mandated by executive order to collaborate in restoration of the Great Lakes (U.S. Department of Commerce, 2007). Several other large-scale collaborative ecosystem restoration initiatives, including those concerned with the Everglades and the San Francisco Bay Delta (Lurie, 2004), were triggered by mandates. McGuire (2006) references the increasing prevalence of other collaborative management arrangements "prescribed by law." Some collaborative processes are de facto mandated when there are no alternative tools available to accomplish required goals. These directives and mandates extend the reach of ECR, but they nonetheless violate the fundamental principle that ECR processes be voluntary.

\section{Voluntary: A Central Tenet of ECR}

The theoretical premise and standard prescription that environmental conflict resolution processes be voluntary has been in place since the beginning of this field. At the risk of tedium but with the objective of demonstrating both how pervasive and enduring this tenet is, this section offers multiple excerpts from the literature on collaboration, dispute resolution, and more recently public administration.

The early pioneers of the ECR field explored the potential of multiparty negotiations in resolution of public disputes and framed a set of definitions and process prescriptions that have stood the test of time. Bacow and Wheeler (1984, p. 26) emphasized that "negotiation is a consensual process from beginning to end. Any party can elect not to participate." "The voluntary nature of negotiations should be stressed," noted Susskind and Cruikshank (1987, p. 96). "Consensus building," they wrote, "requires informal, face-to-face interaction among specially chosen representatives 
of all 'stakeholding' groups; a voluntary effort to seek 'all-gain' rather than 'win-lose' solutions or watered-down political compromise" (p. 11). Cormick (1980) framed perhaps the first working definition, one that remains a standard in the field today: "Mediation is a voluntary process in which those involved in a dispute jointly explore and reconcile their differences." As Moore (1996, p. 19) put it, "Voluntary refers to freely chosen participation and freely made agreement. Parties are not forced to negotiate, mediate or settle by either an internal or external party to a dispute." Examining the first decade of experience with ECR processes, Bingham (1986) offered this definition: "The term 'environmental dispute resolution' refers collectively to a variety of approaches that allow the parties to meet face to face to reach a mutually acceptable resolution of the issues in a dispute or potentially controversial situation. Although there are differences among the approaches, all are voluntary processes" (1986, p. xv).

More recent analyses of collaborative processes involving environmental issues have reconfirmed this long-standing tenet. O'Leary and Bingham (2003, p. 6) write, "Despite the variance in ECR techniques and processes, researchers have identified five characteristics shared by all forms of ECR (with the exception of binding arbitration)," the first of which is that "participation is usually voluntary for all participants." Wondolleck and Yaffee (2000, p. xiii) concur that "such multiparty relationships are voluntary, involve face-to-face interaction and interdependence, and seek specific goals." Daniels and Walker (2001, p. 57) emphasize that "whether collaborative behaviors emerge depends first and foremost on the participants, and there is no practical way or ethical reason to force them to interact collaboratively. Collaboration cannot be forced, scheduled, or required; it must be nurtured, permitted, and promoted."

The growing literature on collaborative public management also identifies voluntary engagement as a key characteristic. Thomson and Perry (2006, p. 25) note that "the implementation of collaboration is complex, not only because participation is voluntary. ... The potential to withdraw from the relationship may be particularly high if collaborations are unable to achieve short-term success." Bingham and O'Leary (2006, p. 162) add that an important prerequisite is "willingness to collaborate." The prescription that dispute resolution processes be voluntary was implicit in the Society of Professionals in Dispute Resolution's (SPIDR's) recommendations for agency sponsorship of collaborative processes. They noted that "in order for an agreement-seeking process to be credible and legitimate, representatives 
of all necessary parties - those involved with or affected by the potential outcomes of the process - should agree to participate, or at least not object to the process going forward" (SPIDR, 1997, p. 9). Huxham (1996) concludes that because "collaboration is voluntary, partners generally need to justify their involvement in it in terms of its contribution to their own aims or refrain from collaborating altogether" (quoted in Thomson and Perry, 2006, p. 26).

In short, it is a long-standing and broadly accepted assumption that a fundamental characteristic of effective ECR processes is that these processes are voluntary; parties can choose whether to participate and whether to remain engaged in a process once under way. This tenet found its way into policy prescription when the directors of the Office of Management and Budget (OMB) and Council on Environmental Quality (CEQ) issued a joint Memorandum on Environmental Conflict Resolution in November 2005, directing federal agencies "to increase the effective use of environmental conflict resolution and build institutional capacity for collaborative problem-solving" (Bolton and Connaughton, 2005, p. 5). The memo summarizes twenty-five years of scholarship and professional practice in a set of eight core principles, one of which is to "ensure balanced, voluntary inclusion of affected/concerned interests; all parties should be willing and able to participate and select their own representative."

\section{Why Voluntariness Matters}

Although the prescription that collaborative processes be voluntary is well established in the literature, there has been surprisingly little explicit exploration of the reasons being voluntary is deemed essential. Nor has there been discussion in the public dispute resolution literature of what might be the implications if collaboration is mandated of participants instead. What appear to be the underlying assumptions of this tenet? How does being voluntary matter to ECR? If we understand the basis for the voluntary prescription, what cautions should accompany a mandated process?

It is difficult to find an explicit explanation in the literature of the reasons voluntary is presumed necessary, but its importance is implicit in many discussions. In particular, two factors stand out. One centers on the dimension of choice implied by a process that is voluntary. The second factor revolves around the concept of procedural justice and its implications for the perceived fairness of a process. 


\section{Voluntary Implies Choice}

When a decision to engage in a collaborative process is made voluntarily, it implies that the parties have, on their own volition, chosen to become involved. As Emerson, O'Leary, and Bingham note, "If we step back and look at the system as a whole, we can ask whether the system is functioning better on some dimension after it affords people the choice to use all the various tools appropriately, including ECR, to optimize environmental policy and its applications" (2004, p. 230). Bacow and Wheeler emphasize the importance of this choice:

We are broadly concerned here with incentives to negotiate, but we must recognize that the decision to enter negotiations is quite different from the decision to come to agreement. A person may be willing to explore the possibility of settlement without committing himself or herself to a consensual resolution. Likewise, the decision not to initiate negotiation may be different from the decision not to accept someone else's invitation to meet, just as the decision to withdraw from negotiations once they have begun is somewhat different from the decision not to talk in the first place. All such choices require a careful weighing of the consequences. As the consequences are likely to differ, so is the nature of the choices [1984, p. 43].

Hence choice implies consideration of alternatives and weighing of consequences; it implies an explicit assessment of the potentials and shortcomings of varying alternatives. The implication is that, lacking choice, this careful weighing does not occur; parties will be less likely to have willingly and thoughtfully considered their interests and options and the potential of a collaborative negotiation process to satisfy those interests.

The purpose of the convening stage of an ECR process is to facilitate informed choices by educating stakeholders "about the nature of the process" and determining "whether or not the stakeholders are willing to participate or if they have better alternatives" (Carlson, 1999, p. 174). A deliberate decision to collaborate suggests that a party understands the collaborative process and its purpose as well as their best alternative to a negotiated agreement (BATNA; Fisher, Ury, and Patton, 1991) should the collaborative process fail, and the party has determined that collaboration will likely better serve their interests. This understanding and perspective matters to a process. As Daniels and Walker (2001, p. 59) explain, it creates "an atmosphere of open communication and collaboration, where 
shared self-interest is the motivation, in a committed search for a mutually beneficial outcome through joint decision making." Choice instills commitment to good faith participation and serious effort to try to achieve the potential in a process. Thomson and Perry $(2006$, p. 28) suggest that "public managers, if they enter collaborations with their eyes open, will be more likely to appreciate, reflect on, and support the relationships that are so critical to collaborative efforts." They conclude with the warning: "Don't collaborate unless you are willing to thoughtfully consider and educate yourself about the nature of the process involved" (p. 29, emphasis in original). A mandate, however, can derail this thoughtful consideration and selfeducation and in so doing undercut a party's perceptions of the value of the process and their incentives to engage in good faith.

\section{Voluntary Implies Fairness}

Choice in our society is also perceived as fair; individuals are not being forced to do something against their will. "Highly visible compulsory processes," Katz (1993, p. 53) notes, "are bound to make some litigants question whether they are being treated fairly." SPIDR guidelines emphasize that "a fair mediation program allows disputants to make informed and voluntary decisions about whether and on what terms to resolve their dispute" (1998, p. 5). If a process is perceived to be fair, parties engage in it with confidence that they will be treated fairly; their interests will be heard and acted on (Lande, 2004; Smith and McDonough, 2001). They are not going to be coerced or co-opted into agreements that are not in their best interests (Fisher, Ury, and Patton, 1991; Goldberg, Green, and Sander, 1986; Susskind and Cruikshank, 1987). As O'Leary and Bingham (2003, p. 8) explain:

Procedural justice, a commonly used framework in ADR research, suggests that participants' satisfaction with an ADR process is a function of their opportunities to control and participate in the process, present views, and receive fair treatment. When participants sense that they have received procedural justice, the perceived legitimacy of the decisions and outcomes increases, which reduces the likelihood that participants will challenge them in the future.

Bean, Fisher, and Eng (2007, p. 451) emphasize that ECR processes "must meet basic ethical guidelines; for example, that the parties own the process [and] that parties have self-determination." Voluntary engagement 
bestows a sense of fairness and consequently legitimacy, instilling a level of respect for the potential of the process and contributing to a participant's commitment to the process and good faith involvement in it.

Procedural justice also has value beyond the process itself, extending an aura of credibility and legitimacy that is important to ECR processes, which by definition reside in the public realm. A sense of procedural justice conveys to those outside the process that it is appropriate and worthwhile because those involved deemed it worth trying and did so willingly. Dukes and Firehock's guide (2001) for environmental advocates underscores the necessity of a fair and transparent ECR process because of the level of vigilant oversight on the part of some individuals and organizations that are wary about collaboration.

\section{Shortcomings of Mandates: Perspectives from Court-Annexed ADR}

If these essential qualities of understanding, commitment, good faith, collaborative mind-set, fairness, and legitimacy are bestowed on a process by virtue of the voluntary nature of the parties' engagement in it, how might their absence have an impact on the dynamics of a mandated process? There has been little explicit attention to the consequences of mandated ECR processes (Good, 2007; Leahy, 2006; Lurie, 2004; Stephenson, 1995). Bingham (1986) was one of the first, along with Gray (1985), Brock (1991), and Brock and Cormick (1989), to express caution about the potential need for and implications of mandated processes in public disputes: "It is not yet known with any certainty whether environmental dispute resolution processes should always be voluntary or whether circumstances exist when they should be required" (p. 53). Bingham was concerned that "accomplishing the intended goals without losing the flexibility that is the basic strength of voluntary dispute resolution processes will be a challenge" (1986, p. 149).

Though lacking in the ECR context, examination of the concerns associated with mandated or compulsory ADR processes in the legal context, and involving small claims or general civil as opposed to environmental or other public disputes, is extensive (see, for example, Golann, 1989; Hedeen, 2005; Katz, 1993; Kirmayer and Wessel, 2004; Lande, 2004; Munro, 1999; Nelle, 1992; Smith, 1998; SPIDR, 1991; Winston, 1996; Wissler, 2002). As Hedeen commented: 
While early mediation programs relied on voluntary participation, many courts now require litigants to try mediation before proceeding to court. Even in mandatory mediation, self-determination is essential: disputants are free to leave the process at any point, with or without settlement, and without coercion. While voluntary mediation may be highlighted in policy and theory, it is not always realized in practice [2005, p. 273].

Katz (1993, p. 2) defines compulsory ADR as "any process in which the parties experience a lack of free choice about their participation." Golann (1989, p. 491) identifies the many reasons mandates may be warranted because parties may not otherwise voluntarily choose ADR, such as lack of awareness of the option, misunderstanding about the process, preference for sustained adversarial exchange, perception of a tactical advantage to continued litigation, being discouraged by their attorneys, and perception that litigation is a superior path to follow. Golann's focus is on civil cases in the courts, but these same types of consideration challenge parties' choices to enter ECR processes and how they behave once engaged (Nabatchi, 2007; O’Leary and Raines, 2001).

Cohen (1991) compares mandated processes in the court context with what he refers to as "pure" or "traditional" mediation, that is, mediation as an option that "parties may choose ... as an alternative to beginning the litigation process" (p. 36). He argues that mandated processes represent a different model of ADR, one that should be acknowledged and its processes "fine-tuned . . . to more precisely fit the needs of those whom it serves" (p. 45). Cohen notes that "settlement rates are lowest when the parties are unenthusiastic about mediation or do not trust the mediator," and "low motivation to resolve the conflict is associated with low probability of settlement" (p. 43). Wissler (2002) has found mixed evidence of the association between mandates and the likelihood of settlement, with some studies suggesting a lower settlement rate while other studies indicate no correlation.

There is an important distinction made in the legal literature between coercion to enter an ADR process and coercion to reach an agreement within that process (Hedeen, 2005; Cohen, 1991; Golann, 1989; Goldberg, Green, and Sander, 1986; Sander, 2000). In theory, a party can always exit a process if they feel their interests are not being met or they are being disadvantaged in some way. Party self-determination and the role of the mediator in ensuring this self-determination is deemed paramount (Hedeen, 
2005; Lande, 2004). Consequently, some have suggested that mandatory mediation is a contradiction in terms or, as Sander (2000, p. 7) put it, an "oxymoron ... mediation means voluntarily agreeing to a result. How can you force someone to voluntarily agree to a result?” Regardless of this logic, there is nonetheless evidence that such coercion does occur (Hedeen, 2005; Wissler, 2002). As Hedeen (p. 286) notes, there is "a gulf between what is promised and what is practiced"; mediator pressure to boost the settlement rate has been observed. Coercion can also be felt in ECR processes because they reside in a highly public and political context that inevitably influences party behavior. For example, in the CALFED San Francisco Bay Delta collaborative ecosystem restoration process, high-level officials invoked what was referred to as the "dead cat" scenario: a balky agency partner was asked if his or her organization wanted to be the one with the "dead cat" at its doorstep if its recalcitrance led to deadlock and subsequent collapse of the process (Lurie, 2004). As Ingram and Fraser (2006, p. 108) observed about this process, "The water issue was of such high visibility for so long that no one wanted the blame for derailing agreement." These pressures kept parties engaged, and they compelled—some might say coerced-agreement on some issues.

The collected judgment is clearly that voluntary engagement is preferred, but most legal analysts accept that compulsory participation is at times necessary in court-connected ADR. Experience has shown that such processes can indeed yield mutually acceptable settlements at considerable time savings to parties and the courts. Just as the promise of ECR has encouraged broader application (Emerson, O'Leary, and Bingham, 2004), this "new understanding of how such processes work" (Katz, 1993, p. 21) has compelled most courts to "enthusiastically enforce statutes, rules, and even agreements for consensual ADR" notwithstanding attorneys being opposed. Both anecdotal evidence (Katz, 1993) and systematic analyses (Golann, 1989; Talcott, 1989; Wissler, 2002) suggest that parties, in hindsight, are satisfied with ADR despite their initial reluctance to participate. Katz (1993) quotes one federal judge who offered a not uncommon observation: "I do know that but for my making summary jury trials mandatory in these cases, they would not have occurred. I know also that the attorney who objected to the first summary jury trial he was required to participate in is now the biggest local fan of the procedure" (fn. 158).

Katz (1993, p. 21) warns, however, that "consensual ADR depends on cooperation," and parties forced to collaborate may do so uncooperatively, making the effort fruitless: "Many of the problems evidenced by ADR 
litigation would be removed if all participation were voluntary ... the more troubling questions of good faith and meaningful participation would appear irrelevant if parties could simply refuse to take part in the procedure in question" (Katz, 1993, p. 53). She concludes:

On balance, then, the argument for voluntariness appears strong. First, there is little evidence that compulsion produces greater efficiency or greater justice. Second, there is at least some evidence that some participants feel undue pressure and believe their right to a fair trial is violated by compulsory procedures. Third, voluntary procedures would eliminate a great deal of potential litigation over issues of compulsion, and particularly over the troublesome question of the duty to participate in good faith. Fourth, voluntariness is consistent with the underlying philosophy of ADR [Katz, 1993, p. 54; emphasis added].

Peltz (1999) similarly argues that "mediation is the process most unlike adjudication, and arguably its integrity is preserved only if participation is voluntary" (p. 1; emphasis added).

In sum, voluntariness is perceived to be an essential dimension of ADR, embedded in the field's core philosophy and a factor that preserves the integrity of collaborative processes. The benefits of voluntary engagement to the functioning of these processes are clear and the shortcomings favor good caution. Nevertheless, like many mediated civil cases, not all ECR processes are voluntary, and this reality begs attention parallel to that given to court-connected ADR. When and how might the impact of nonvoluntary engagement be felt in public dispute resolution processes? Moreover, what challenges should interveners be attentive to when parties may be unwilling participants in a public environmental dispute resolution process?

\section{Degrees of Choice and Their Implications}

Choice is not a binary concept. Rather, there are degrees of choice and hence degrees to which participation in a collaborative process is voluntary. As Hedeen (2005, p. 273) put it, "All mediations are voluntary, but some are more voluntary than others." Figure 1 depicts a continuum of voluntary engagement in public dispute resolution processes, with parties willingly engaged at one end and required to participate at the other end. Its purpose is to identify nuances in participant choices and predispositions 
about an ECR process in order to identify where variations in process dynamics are likely that will have bearing on intervention strategies. The core characteristics of processes along this continuum are aligned; they are all representative of the key parties with a stake or role in resolving a particular dispute or problem. The processes are intended to promote problem solving or dispute resolution by encouraging communication, understanding, and collaboration, and they are consensus-seeking. However, movement along the continuum from left to right increasingly violates the core principle that ECR processes be voluntary.

As the position of a process along this continuum moves from a high degree of voluntariness to a low degree, the starting dynamic will likely vary, and these variations have significant implications for process management. An intervener enters a very different process when the participants are willingly engaged than when they are present under duress. Consider, for example, the four positions spotlighted on the continuum.

\section{Willing Choice}

Willing engagement in a collaborative process is the product of the individual participant's consideration and choice. Cohen (1991) refers to this as a "pure" choice because the decision to engage is made wholly by the individual participant. A party presented with the collaborative option has the opportunity to consider and decide by his or her own free will whether or not to participate. The implication of a choice made willingly is that the parties understand their interests and objectives as well as the process and its purpose, and the parties will be committed to a good faith effort to the process.

Figure 1. Degrees of Voluntary Participation and Their Potential Effect on Participant Predispositions

\begin{tabular}{|ll|}
\hline High & Low \\
\hline Nature of choice: & \\
Willing choice Begrudged choice & Someone else's choice No choice \\
Entering attitude: & \\
Good faith/commitment & Ambivalence/reserved judgment \\
Uncertainty/wariness & Resistance/skepticism \\
\hline
\end{tabular}




\section{Begrudged Choice}

Sometimes parties enter a process begrudgingly, not willingly. They are responding to factors tangential to the dispute or problem. They might feel obliged to participate because of pressure from other parties or the convener (Hedeen and Coy, 2000; Nelson, 1990). Some agency bureaucrats may prefer to just go it alone and render decisions within traditional administrative procedures but might feel public or political pressure to collaborate. Sometimes factors that are unconnected to the process agenda, in particular "shadow issues" (Kolb and Williams, 2003), compel a party's participation but distract the party from the key issues on the table. If parties make a decision to participate begrudgingly, they are more likely to enter a process with some level of ambivalence, reserving judgment about its potential and the value of their participation in it, and perhaps entering with concerns and objectives other than those central to the process.

\section{Someone Else's Choice}

Not infrequently, it is someone else's decision that brings an individual participant to the table. In these cases it is usually a superior's assessment that collaboration makes sense for an organization, whether for strategic or substantive reasons. When a participant is acting on someone else's decision, he or she as an individual has not benefited from assessing the process and its potential and deciding for himself or herself that it is a preferred path and should be pursued. The person is more likely to enter the process uncertain about its scope, purpose, and functioning, and with some wariness about his or her role in it.

\section{No Choice}

At the far end of the continuum are case situations in which the parties essentially have no choice; a mandate has directed them to the table. In effect, participants in mandated processes have received a summons (Hedeen and Coy, 2000), not an invitation to be thoughtfully considered. Parties compelled by mandate to engage in processes located at this far end of the continuum will often be resistant to the idea and skeptical about its value (Lurie, 2004). They are more likely to enter with their adversarial frame intact and without acknowledgment of, or respect for, the perspectives of the other parties (Daniels and Walker, 2001). 


\section{A Crack in the Foundation?}

Compulsory participation, whatever its source, can challenge the very essence of what makes collaboration work by undermining key foundational elements of ECR processes. Much has been written about antecedents to collaboration and the essential elements of collaborative ECR processes (see, for example, Cormick, 1980; Daniels and Walker, 2001; Fisher, Ury, and Patton, 1991; Moore, 1996; Susskind, McKearnan, and Thomas-Larmer, 1999; Thomson and Perry, 2006; U.S. Institute for Environmental Conflict Resolution, 2006; Wondolleck and Yaffee, 2000; Wood and Gray, 1991). A basic synthesis of this extensive literature suggests that the foundation of effective ECR processes is constructed of issues that are amenable to collaborative resolution, incentives for collaborative engagement, process qualities that encourage cooperative behavior, and a process structure that accommodates and effectively guides collaborative interaction. Here is a simple summary of these critical building blocks, indicating which are likely to be compromised when participants engage in a process less than voluntarily. The issue characteristics that make a situation amenable to collaborative resolution include a high level of interdependence between the parties, complexity that impedes the possibility of unilateral resolution, absence of fundamental rights or values, and need for sharing resources, information, or risk such that parties necessarily work together. These issue characteristics are necessary but not sufficient conditions for constructive collaboration.

Building Blocks of Environmental Conflict Resolution (Italicized Elements May Be Strained or Lacking in a Mandated Process)

I. Issue characteristics: Are the issues amenable to collaborative resolution?

High levels of interdependence

Need for resource, information, or risk sharing

Issue complexity

Unilateral resolution by any party not possible

No fundamental rights or values involved

II. Parties' incentives: Do the parties perceive incentives to collaborate?

Sense of urgency

Recognition of interdependence

Recognition of need to work with others

Alternative options not preferred 
III. Process qualities: Does the process dynamic embody qualities essential to cooperative behavior?

\section{Commitment \\ Good faith \\ Collaborative mind-set}

Perception of fairness and legitimacy

IV. Process structure: Is the process structured and managed to support and guide collaborative problem solving?

Representative

Informed

Clear purpose

Issue- or problem-focused

Effective communication

Efficient management

Even if issues are amenable, the parties must still perceive incentives to collaborate before they will voluntarily join a process. The second building block contains those elements that influence a party's motivation to engage in a collaborative process, in particular recognition of interdependence and the need to work together, a sense of urgency to deal with the issues in dispute, and a perception that collaboration is the preferred approach. The third building block contains the process qualities that instill cooperative behavior among participants, in particular commitment, good faith, and perception of fairness and legitimacy, all of which embody a collaborative mind-set and encourage respectful interaction. Finally, the fourth building block concerns the process structures that support and guide interaction toward constructive resolution, capitalizing on the collaborative potential inherent in the issue characteristics, incentives, and behavioral qualities of participants. These structural elements include appropriate representation, clarity of purpose, informed deliberation, problem or issue focus, effective communication, and efficient management.

As indicated by the italicized elements in the list, the degree to which participation is voluntary can influence both perceived incentives and essential process qualities, and in so doing this can weaken the foundation supporting an ECR process. If parties do not recognize their interdependence and need to work together, perceive an urgency to resolve the issue(s) in dispute, or acknowledge that collaboration is the preferred path for addressing their interests, then they are less likely to enter the process with 
commitment and in good faith. They will be less likely to judge their involvement as fair and more likely to resist (at least initially) constructive engagement. It is important to note that this seeming crack in the theoretical foundation has not undermined ECR practice. However, lack of acknowledgment of its presence has diverted needed attention from examination of its implications for practice.

\section{Conclusion}

Voluntary engagement in ECR processes is the ideal. It ensures understanding, commitment, and good-faith participation as well good reason for this tenet to remain firmly in place. As Dukes and Firehock (2001, p. viii) note, "Consensus processes can be powerful, but they are useful only to the extent that participants fully understand and value the requirements of the process." Nevertheless, as discussed, not all situations are amenable to or consistent with voluntary participation, and this reality challenges both the principle and the process. As Daniels and Walker warn (2001, p. 64):

It is unrealistic to merely announce that a collaboration is beginning and expect the current relationships and patterns of behavior to change. Collaboration requires innovative decision-building structures designed with considerable attention to the incentives that they create. If they do not establish clear rewards for collaboration and disincentives for competition, there is no reason to expect much change in behavior." ECR process design and management must account for these particular needs when a process involves less-than-voluntary engagement.

ECR professionals have considerable experience intervening in processes all along the continuum of voluntariness depicted in Figure $1 .^{1}$ Their experience and insights should be more explicitly captured in order to enhance professional practice as well as establish more accurate expectations among policy makers, public managers, and potential participants in processes that may violate the voluntary prescription. Macfarlane and Mayer (2005) discuss the troubling disconnect between collaboration theory and practice and call for creating the "genuine marriage of rigorous theory and grounded practice wisdom that can be taken seriously by academics and practitioners alike" (p. 259). This brief examination of the voluntary tenet provides one immediate example wherein this marriage might readily occur. By leaving the voluntary tenet unexamined, the field inadvertently diverts attention 
from important variations among ECR processes and deliberate development of nuanced intervention strategies that acknowledge the particular needs of mandated and other not-fully-voluntary processes. The fact that ECR professionals have experience with processes across the continuum suggests that there are ready lessons to be learned. Moreover, their experience suggests that whether or not a process is voluntary may be less critical than how it is managed, so as to instill those qualities associated with voluntary engagement, that is, intervention strategies that ensure clarity in understanding of the process, instill a desire to be involved, demonstrate collaborative potential relative to alternatives, foster a sense of commitment and responsibility, establish relationships that highlight interconnections and respectful exchange, and embed standards of fairness.

\section{Note}

1. During presentation of this simple continuum at the Association for Conflict Resolution-Environment and Public Policy section meeting in Cambridge, Massachusetts, in June 2006, several mediators in the audience commented that a good portion of their projects fall toward the middle and right side of the continuum, where the degree of voluntary engagement of individual participants has been constrained. These practitioners sought guidance from one another about the array of intervention challenges each had encountered and strategies they had employed for managing processes that fall at different points along the continuum.

\section{References}

Agranoff, R. Managing Within Networks: Adding Value to Public Organizations. Washington, D.C.: Georgetown University Press, 2007.

Bacow, L. S., and Wheeler, M. Environmental Dispute Resolution. New York: Plenum, 1984.

Bardach, E. Getting Agencies to Work Together: The Practice and Theory of Managerial Craftsmanship. Washington, D.C.: Brookings Institution, 1998.

Bean, M., Fisher, L., and Eng, M. "Assessment in Environmental and Public Policy Conflict Resolution: Emerging Theory, Patterns of Practice, and a Conceptual Framework." Conflict Resolution Quarterly, 2007, 24(4), 447-468.

Bernard, T., and Young, J. M., The Ecology of Hope: Communities Collaborate for Sustainability. New Society, 1996.

Bingham, G. Resolving Environmental Disputes: A Decade of Experience. Washington, D.C.: Conservation Foundation, 1986.

Bingham, L. B., and O'Leary, R. "Conclusion: Parallel Play, Not Collaboration: Missing Questions, Missing Connections." Public Administration Review, 2006, supplement to vol. 66, 161-167. 
Bolton, J., and Connaughton, J. L. Memorandum on Environmental Conflict Resolution. Washington, D.C.: Office of Management and Budget and President's Council on Environmental Quality, 2005.

Brick, P., and Snow, D. (eds.). Across the Great Divide: Explorations in Collaborative Conservation and the American West. Washington, D.C.: Island Press, 2000.

Brock, J. "Mandated Mediation: A Contradiction in Terms." Villanova Environmental Law Journal. 1991, 2, 57-87.

Brock, J., and Cormick, G. W. "Can Negotiation Be Institutionalized or Mandated? Lessons from Public Policy and Regulatory Conflicts.” In K. Kressel, D. G. Pruitt, and Associates (eds.), Mediation Research. San Francisco: JosseyBass, 1989.

Carlson, C. "Convening." In L. Susskind, McKearnan, S., and Thomas-Larmer, J. (eds.), The Consensus Building Handbook: A Comprehensive Guide to Reaching Agreement, Thousand Oaks, Calif.: Sage, 1999.

Cheng, A. S. "Build It and They Will Come? Mandating Collaboration in Public Lands Planning and Management." Natural Resources Journal, 2006, 46, 841-858.

Cohen, L. "Mandatory Mediation: A Rose by Any Other Name." Mediation Quarterly, 1991, 9(1), 33-46.

Cormick, G. W. "The 'Theory' and Practice of Environmental Mediation.” Environmental Professional, 1980, 2(1) 24-33.

Daniels, S. E., and Walker, G. B. Working Through Environmental Conflict: The Collaborative Learning Approach. Westport, Conn.: Praeger, 2001.

Dukes, E. F. "What We Know About Environmental Conflict Resolution: An Analysis Based on Research." Conflict Resolution Quarterly, 2004, 22(1-2), 191-220.

Dukes, E. F., and Firehock, K. Collaboration: A Guide for Environmental Advocates. Charlottesville, Va.: Institute for Environmental Negotiation, Wilderness Society, National Audubon Society, 2001.

Emerson, K., O'Leary, R., and Bingham, L. B. "Commentary: Comment on Frank Dukes's 'What We Know About Environmental Conflict Resolution."' Conflict Resolution Quarterly, 2004, 22(1-2), 221-231.

Fisher, R., Ury, W., and Patton, B. Getting to Yes: Negotiating Agreement Without Giving In (2nd ed.). New York: Penguin Books, 1991.

Golann, D. Making ADR Mandatory: The Constitutional Issues. Oregon Law Review, 1989, 68, 487-568.

Goldberg, S. B., Green, E. D., and Sander, F.E.A. "ADR Problems and Prospects: Looking to the Future." Judicature, 1986, 69(5), 291-299.

Good, J. E. "Confounding Collaboration: The Federal Advisory Committee Act's Impact on BLM Resource Advisory Councils." Unpublished master's thesis, School of Natural Resources and Environment, University of Michigan, Ann Arbor, 2007.

Gray, B. "Conditions Facilitating Interorganizational Collaboration." Human Relations, 1985, 38(10), 911-936. 
Hedeen, T. "Coercion and Self-Determination in Court-Connected Mediation: All Mediations Are Voluntary, But Some Are More Voluntary Than Others." Justice System Journal, 2005, 26(3), 273-291.

Hedeen, T., and Coy, P. G. "Community Mediation and the Court System: The Ties That Bind.” Mediation Quarterly, Summer 2000, 17(4), 351-367.

Heikkila, T., and Gerlak, A. K. "The Formation of Large-scale Collaborative Resource Management Institutions: Clarifying the Roles of Stakeholders, Science, and Institutions." Policy Studies Journal, 2005, 33(4), 583-612.

Huxham, C. "Collaboration and Collaborative Advantage." In C. Huxham (ed.), Creating Collaborative Advantage. Thousand Oaks, Calif.: Sage, 1996.

Ingram, H., and Fraser, L. "Path Dependency and Adroit Innovation: The Case of California Water." In R. Repetto (ed.), Punctuated Equilibrium and the Dynamics of U.S. Environmental Policy. New Haven, Conn.: Yale University Press, 2006.

Katz, L. V. "Compulsory Alternative Dispute Resolution and Voluntarism: TwoHeaded Monster or Two Sides of the Coin?" Journal of Dispute Resolution, 1993, 1993(1), 1-55.

Kirmayer, K., and Wessel, J. “An Offer One Can't Refuse: Mediate.” National Law Journal, Oct. 18, 2004.

Kolb, D. M., and Williams, J. Everyday Negotiation: Navigating the Hidden Agendas in Bargaining. San Francisco: Jossey-Bass, 2003.

Koontz, T. M., and others. Collaborative Environmental Management: What Roles for Government? Washington, D.C.: Resources for the Future, 2004.

Lande, J. "Commentary: Focusing on Program Design Issues in Future Research on Court-Connected Mediation." Conflict Resolution Quarterly, 2004, 22(1-2), 89-100.

Leahy, I. "Mandated Collaboration: An Assessment of Resource Advisory Committees." Communities and Forests: The Newsletter of the Communities Committee of the Seventh American Forest Congress, 2006, 10(1), 4-5.

Lurie, S. D. "Interorganizational Dynamics in Large-Scale Integrated Resources Management Networks: Insights from the CALFED Bay-Delta Program." Unpublished doctoral dissertation, School of Natural Resources and Environment, University of Michigan, Ann Arbor, 2004.

Macfarlane, J., and Mayer, B. "What Theory? How Collaborative ProblemSolving Trainers Use Theory and Research in Training and Teaching." Conflict Resolution Quarterly, 2005, 23(2), 259-276.

Margerum, R. D. "A Typology of Collaboration Efforts in Environmental Management." Environmental Management, 2008, 41(4), 487-500.

McGuire, M. "Collaborative Public Management: Assessing What We Know and How We Know It." Public Administration Review, 2006, supplement to Vol. 66, 33-43.

Moore, C. W. The Mediation Process: Practical Strategies for Resolving Conflict (2nd ed.). San Francisco: Jossey-Bass, 1996.

Munro, M. M. "Musings on the Consequences of Mandatory Mediation." Advocate, 1999, 57(2), 193-200. 
Nabatchi, T. "The Institutionalization of Alternative Dispute Resolution in the Federal Government." Public Administration Review, 2007, 67(4), 646-661.

Nelle, A. "Making Mediation Mandatory: A Proposed Framework." Ohio State Journal on Dispute Resolution, 1992, 7(2), 287-313.

Nelson, K. "Common Ground Consensus Project." In J. Crowfoot and J. Wondolleck (eds.), Environmental Disputes: Community Involvement in Conflict Resolution. Washington, D.C.: Island Press, 1990.

O'Leary, R., and Bingham, L. B. (eds.). The Promise and Performance of Environmental Conflict Resolution. Washington, D.C.: Resources for the Future, 2003.

O'Leary, R., and Raines, S. S. "Lessons Learned from Two Decades of Alternative Dispute Resolution Programs and Processes at the U.S. Environmental Protection Agency." Public Administration Review, 2001, 61(6), 682-692.

Peltz, S. "Only for a Season: Mandatory Mediation as a Temporary Measure." Northfield, Minn.: Carleton University, 1999.

Sabatier, P. A., and others. Swimming Upstream: Collaborative Approaches to Watershed Management. Cambridge, Mass.: MIT Press, 2005.

Sander, F.E.A. "The Future of ADR: The Earl F. Nelson Memorial Lecture." Journal of Dispute Resolution, 2000, (1), 3-10.

Smith, G. "Unwilling Actors: Why Voluntary Mediation Works, Why Mandatory Mediation Might Not." Osgoode Hall Law Journal, 1998, 36(4), 847-885.

Smith, P. D., and McDonough, M. H. "Beyond Public Participation: Fairness in Natural Resource Decision Making." Society and Natural Resources, 2001, 14(3), 239-241.

Society of Professionals in Dispute Resolution (SPIDR). "Dispute Resolution As It Relates to the Courts: Mandated Participation and Settlement Coercion." Arbitration Journal, Mar. 1991, 38-47.

Society of Professionals in Dispute Resolution (SPIDR). Best Practices for Government Agencies: Guidelines for Using Collaborative Agreement-Seeking Processes. Washington, D.C.: SPIDR, 1997.

Society of Professionals in Dispute Resolution (SPIDR). Guidelines for Voluntary Mediation Programs Instituted by Agencies Charged with Enforcing Workplace Rights. Washington, D.C.: SPIDR, 1998.

Stephenson, M. O. "Rescuing ADR from Its Advocates." Public Administration Review, 1995, 55(4), 385-388.

Susskind, L., and Cruikshank, J. Breaking the Impasse: Consensual Approaches to Resolving Public Disputes. New York: Basic Books, 1987.

Susskind, L., McKearnan, S., and Thomas-Larmer, J. (eds.). The Consensus Building Handbook: A Comprehensive Guide to Reaching Agreement. Thousand Oaks, Calif:: Sage, 1999.

Talcott, B. W. "Court-Ordered Mediation in Florida." In S. K. Erickson (ed.), Legal Issues Affecting the Practice of Mediation. Mediation Quarterly, Spring 1989, 23, 77-84. 
Thomson, A. M., and Perry, J. L. "Collaboration Processes: Inside the Black Box." Public Administration Review, 2006, supplement to vol. 66, 20-32.

U.S. Department of Commerce, National Oceanic and Atmospheric Administration. "Advancing NOAA's Priorities Through Regional Collaboration." Washington, D.C.: U.S. GPO, Apr. 2007.

U.S. Institute for Environmental Conflict Resolution. "ECR Performance Evaluation: An Inventory of Indicators." Oct. 2006. www.ecr.gov.

Van de Wetering, S. B., and McKinney, M. "The Role of Mandatory Dispute Resolution in Federal Environmental Law: Lessons from the Clean Air Act." Journal of Environmental Law and Litigation, 2006, 21(1), 1-45.

Weber, E. P. Bringing Society Back In: Grassroots Ecosystem Management, Accountability, and Sustainable Communities. Cambridge, Mass.: MIT Press, 2003.

Weber, E. P., and Khademian, A. M. "Wicked Problems, Knowledge Challenges, and Collaborative Capacity Builders in Network Settings." Public Administration Review, 2008, 68(2), 334-349.

Winston, D. S. "Participation Standards in Mandatory Mediation Statutes: 'You Can Lead a Horse to Water. ... "' Ohio State Journal on Dispute Resolution, 1996, 11, 187-206.

Wissler, R. L. "Court-Connected Mediation in General Civil Cases: What We Know from Empirical Research." Ohio State Journal on Dispute Resolution, 2002, 17(3), 641-702.

Wondolleck, J. M., and Yaffee, S. L. Making Collaboration Work: Lessons from Innovation in Natural Resource Management. Washington, D.C.: Island Press, 2000.

Wood, D., and Gray, B. "Toward a Comprehensive Theory of Collaboration." Journal of Applied Behavioral Science, 1991, 27(2), 139-162.

Julia M. Wondolleck is an associate professor in the School of Natural Resources and Environment at the University of Michigan, where she conducts research and teaches courses in environmental conflict management, negotiation of environmental disputes, mediation skills, and collaboration in ecosystem management. She is the author of Public Lands Conflict and Resolution: Managing National Forest Disputes; Environmental Disputes: Community Involvement in Conflict Resolution (with James Crowfoot), and Making Collaboration Work: Lessons from Innovation in Natural Resource Management (with Steven Yaffee). 